\title{
Systematic Exploration of the Synthetic Parameters for the Production of Dynamic $\mathrm{VO}_{2}(\mathrm{M1})$
}

\author{
Giulia Bragaggia $^{1,2}$, Andrea Cacciatore ${ }^{1,3}$, Elisa Poffe ${ }^{1,2}$, Claudia Capone ${ }^{3}$, Federico Zorzi ${ }^{4,5}$, Valerio Causin ${ }^{1}$ \\ and Silvia Gross ${ }^{1,2, *}$ \\ 1 Dipartimento di Scienze Chimiche, Università degli Studi di Padova, Via Marzolo 1, 35131 Padova, Italy; \\ giulia.bragaggia@unipd.it (G.B.); a.cacciatore@italcementi.it (A.C.); elisa.poffe@gmail.com (E.P.); \\ valerio.causin@unipd.it (V.C.) \\ 2 INSTM, Consorzio Interuniversitario per la Scienza e Tecnologia dei Materiali, Via Giusti 9, \\ 50121 Firenze, Italy \\ 3 Italcementi S.p.A., HeidelbergCement Group, Via Stezzano 87, 24126 Bergamo, Italy; c.capone@italcementi.it \\ 4 CEASC, Centro di Analisi e Servizi per la Certificazione, Via Jappelli 1/A, 35131 Padova, Italy; \\ federico.zorzi@unipd.it \\ 5 Dipartimento di Geoscienze, Università degli Studi di Padova, Via Gradenigo 6, 35131 Padova, Italy \\ * Correspondence: silvia.gross@unipd.it
}

check for updates

Citation: Bragaggia, G.; Cacciatore, A.; Poffe, E.; Capone, C.; Zorzi, F.; Causin, V.; Gross, S. Systematic Exploration of the Synthetic Parameters for the Production of Dynamic $\mathrm{VO}_{2}(\mathrm{M} 1)$. Molecules 2021, 26, 4513. https://doi.org/10.3390/ molecules 26154513

Academic Editors: Giuseppe Cirillo and Hom Nath Dhakal

Received: 22 May 2021

Accepted: 22 July 2021

Published: 27 July 2021

Publisher's Note: MDPI stays neutral with regard to jurisdictional claims in published maps and institutional affiliations.

Copyright: (c) 2021 by the authors. Licensee MDPI, Basel, Switzerland. This article is an open access article distributed under the terms and conditions of the Creative Commons Attribution (CC BY) license (https:/ / creativecommons.org/licenses/by/ $4.0 /)$.

\begin{abstract}
Thermochromic dynamic cool materials present a reversible change of their properties wherein by increasing the temperature, the reflectance, conductivity, and transmittance change due to a reversible crystalline phase transition. In particular, vanadium (IV) dioxide shows a reversible phase transition, accompanied by a change in optical properties, from monoclinic $\mathrm{VO}_{2}(\mathrm{M} 1)$ to tetragonal $\mathrm{VO}_{2}(\mathrm{R})$. In this paper, we report on a systematic exploration of the parameters for the synthesis of vanadium dioxide $\mathrm{VO}_{2}$ (M1) via an easy, sustainable, reproducible, fast, scalable, and low-cost hydrothermal route without hazardous chemicals, followed by an annealing treatment. The metastable phase $\mathrm{VO}_{2}(\mathrm{~B})$, obtained via a hydrothermal route, was converted into the stable $\mathrm{VO}_{2}$ (M1), which shows a metal-insulator transition (MIT) at $68{ }^{\circ} \mathrm{C}$ that is useful for different applications, from energy-efficient smart windows to dynamic concrete. Within this scenario, a further functionalization of the oxide nanostructures with tetraethyl orthosilicate (TEOS), characterized by an extreme alkaline environment, was carried out to ensure compatibility with the concrete matrix. Structural properties of the synthesized vanadium dioxides were investigated using temperaturedependent X-ray Diffraction analysis (XRD), while compositional and morphological properties were assessed using Scanning Electron Microscopy, Energy Dispersive X-ray Analysis (SEM-EDX), and Transmission Electron Microscopy (TEM). Differential Scanning Calorimetry (DSC) analysis was used to investigate the thermal behavior.
\end{abstract}

Keywords: thermochromic materials; $\mathrm{VO}_{2}(\mathrm{M} 1)$; $\mathrm{VO}_{2}(\mathrm{R})$; metal-insulator transition (MIT); hydrothermal synthesis; functionalization

\section{Introduction}

Thermochromic materials represent a wide and extensive class of materials that falls within the field of the chromogenic device technology [1]. They are particularly used to vary the throughput of visible light for several applications, e.g., smart windows [2,3]. These materials show a metal-insulator transition (MIT) phenomenon associated with resistivity, transmittance, conductivity, and reflectance changes [4], and are mainly employed to reduce buildings' energy consumption. Buildings account for around $30-40 \%$ of the world's total energy intake due to the excessive use of lighting, air conditioning, and heating [5,6]. The atmospheric content of carbon dioxide has risen from $315 \mathrm{ppm}$ at the end of the 1950s to 419 ppm in 2021, with a range of uncertainty of 0.1 ppm [7], mostly due to the burning of fossil fuels and with relevant consequences for life on Earth [8]. 
Because of their high energy uptake, buildings represent one of the most crucial issues in this area and a large number of technologies has been explored, with particular focus on smart windows, which have variable throughput of solar energy and visible light that can lower energy consumption. Windows are known to be the most inefficient elements of buildings. Smart windows employ chromogenic materials [9], specifically those with electrochromic or thermochromic properties. A wide range of materials has been studied for this application, including titanium oxides $\left(\mathrm{Ti}_{2} \mathrm{O}_{3}, \mathrm{Ti}_{3} \mathrm{O}_{5}\right)$ [10], perovskites $\left(\mathrm{LnNiO}_{3}\right.$, $\mathrm{Ln}=\mathrm{Pr}, \mathrm{Nd}, \mathrm{Sm}, \mathrm{Eu})$ [11], and vanadium oxides $\left(\mathrm{V}_{2} \mathrm{O}_{3}, \mathrm{~V}_{6} \mathrm{O}_{13}, \mathrm{~V}_{4} \mathrm{O}_{7}, \mathrm{VO}_{2}\right)$ [12]. Within this context, vanadium dioxide, $\mathrm{VO}_{2}$, represents one of the most promising and widely studied inorganic thermochromic materials [13], since its polymorph $\mathrm{VO}_{2}(\mathrm{M})$ shows a MIT at a temperature of $\tau_{c} \approx 68{ }^{\circ} \mathrm{C}$ [14]. This transition is followed by a reversible crystal structure transformation from a low-temperature insulator phase, $\mathrm{VO}_{2}(\mathrm{M})$, to a hightemperature metal phase, $\mathrm{VO}_{2}(\mathrm{R})$. As a consequence, a change in the optical properties of vanadium dioxide occurs, namely an increase in the reflectance and a decrease in the transmittance, in addition to a higher conductivity. Vanadium dioxide exists in 10 different polymorphs, among which the most common are $\mathrm{VO}_{2}(\mathrm{~B}), \mathrm{VO}_{2}(\mathrm{M})$, and $\mathrm{VO}_{2}(\mathrm{D})$, belonging to the monoclinic crystal system; $\mathrm{VO}_{2}(\mathrm{~A})$ and $\mathrm{VO}_{2}(\mathrm{R})$, with tetragonal structures; and $\mathrm{VO}_{2}(\mathrm{P})$, which belongs to the orthorhombic crystal system. The $\mathrm{VO}_{2}(\mathrm{~B})$ polymorph, space group $\mathrm{C} 2 / \mathrm{m}$, is an interesting cathode material for Li-ion batteries and shows a reversible structure switch from amorphous to crystalline phase under high pressure $[15,16] ; \mathrm{VO}_{2}(\mathrm{D})$, space group $\mathrm{P} 2 / \mathrm{c}$, is a new $\mathrm{VO}_{2}$ phase observed by Qu et al. [17] that can transform to $\mathrm{VO}_{2}(\mathrm{R})$ at about $593 \mathrm{~K}[18]$.

The $\mathrm{VO}_{2}(\mathrm{~A})$ polymorph, space group $\mathrm{P}_{2} / \mathrm{ncm}$, is an intermediate phase between $\mathrm{VO}_{2}(\mathrm{~B})$ and $\mathrm{VO}_{2}(\mathrm{R})$ and undergoes a MIT at $162^{\circ} \mathrm{C}$ [19], while $\mathrm{VO}_{2}(\mathrm{P})$, space group Pbnm, is a paramontroseite $\mathrm{VO}_{2}$ mineral that can be transformed to $\mathrm{VO}_{2}(\mathrm{M})$ by fast annealing [20]. The $\mathrm{VO}_{2}(\mathrm{M})$ and $\mathrm{VO}_{2}(\mathrm{R})$ oxides, with space groups $\mathrm{P} 2_{1} / \mathrm{c}$ and $\mathrm{P}_{2} / \mathrm{mnm}$, respectively, represent the most interesting polymorphs of vanadium dioxide, since they display a reversible phase transition near room temperature. Changes in the crystal structure due to both Peierls and Mott' mechanisms [21] contribute to the phase transition. Furthermore, using micro-Raman spectroscopy, Shao et al. [22] revealed the presence of two monoclinic phases, $\mathrm{VO}_{2}(\mathrm{M} 1)$ and $\mathrm{VO}_{2}(\mathrm{M} 2)$, and a triclinic phase, $\mathrm{VO}_{2}(\mathrm{~T})$, induced by temperature or strain, that can promote the transition to $\mathrm{VO}_{2}(\mathrm{R})$.

With the purpose of obtaining a pure $\mathrm{VO}_{2}(\mathrm{M} 1)$ phase, hydrothermal synthesis was employed and optimization was carried out of several synthetic parameters, including the vanadium precursor/reducing agent molar ratio, the reaction time, and the temperature required for the formation of the phase-pure $\mathrm{VO}_{2}(\mathrm{M} 1)$. Furthermore, the influences of different vanadium precursors and reducing agents were investigated. In view of a possible application as additive for concrete, functionalization with a silica layer was performed, with the purpose of enhancing the compatibility with concrete. A stability test at $\mathrm{pH}=11$ on the functionalized vanadium dioxide was implemented to mimic the alkaline concrete's $\mathrm{pH}$. Once optimal conditions were established, a scale-up process was implemented by maintaining the vanadium precursor/reducing agent molar ratio constant and increasing the molar ratio with respect to the solvent. These variations did not produce any difference in the XRD analyses.

Therefore, this synthesis proved to be fast, easy, reproducible, scalable, and low cost with respect to the synthetic routes reported in the literature. These syntheses involve the use of hazardous chemicals and/or long reaction times, two conditions not compliant with future industrial production.

This work was performed in collaboration with Italcementi S.p.A. within the "COOL IT, progetto finanziato a valere sul Fondo di Ricerca di Sistema Elettrico" project. Among the activities performed as part of this project, this research aimed at lowering buildings' energy uptake by integrating inorganic $\mathrm{VO}_{2}$ powder into concrete. 


\section{Results and Discussion}

\subsection{Synthesis and Characterization of $\mathrm{VO}_{2}(B)$ and Its Conversion to $\mathrm{VO}_{2}(\mathrm{M} 1)$}

The samples were prepared via hydrothermal synthesis, since this route is wellestablished $[23,24]$ and widely used for its flexibility in tuning different parameters such as concentration, additives, temperature, and reaction time. Furthermore, this synthesis aimed to optimize synthetic parameters in terms of yield and cost-effectiveness, and to develop a final scale-up process for possible future applications in industrial processes. In particular, the influence of two different vanadium precursors, vanadium pentoxide $\left(\mathrm{V}_{2} \mathrm{O}_{5}\right)$ and ammonium metavanadate $\left(\mathrm{NH}_{4} \mathrm{VO}_{3}\right)$, and two different reducing agents, citric acid monohydrate and oxalic acid, were studied. The vanadium precursor/reducing agent molar ratio was also screened, along with the reaction time and the temperature.

The synthesized samples are summarized in Table 1.

Table 1. List of the samples synthesized via hydrothermal synthesis by changing the vanadium precursors, the molar ratios vanadium precursor $(\mathrm{V})$ /reducing agent $(\mathrm{R})$ /solvent $(\mathrm{S})$, the temperature, and the reaction time.

\begin{tabular}{|c|c|c|c|c|c|c|}
\hline Samples & $\begin{array}{c}\text { Vanadium } \\
\text { Precursor (V) }\end{array}$ & $\begin{array}{l}\text { Reducing Agent } \\
\text { (R) }\end{array}$ & $\begin{array}{l}\text { Molar Ratio } \\
\text { (V:R:S) }\end{array}$ & $\begin{array}{c}\text { Temperature } \\
\left({ }^{\circ} \mathrm{C}\right)\end{array}$ & Time (h) & XRD Output \\
\hline $\begin{array}{l}\mathrm{V} 1_{1.2 \_} 24 \mathrm{~h} \\
\mathrm{~N} 1_{1.2 \_} 24 \mathrm{~h}\end{array}$ & $\begin{array}{c}\mathrm{V}_{2} \mathrm{O}_{5} \\
\mathrm{NH}_{4} \mathrm{VO}_{3}\end{array}$ & $\begin{array}{c}\text { Citric acid } \\
\text { monohydrate }\end{array}$ & \multirow{2}{*}{ 1:1.2:605 } & \multirow{2}{*}{160} & \multirow{2}{*}{24} & $\begin{array}{l}\text { Mixed oxides } \\
\text { Mixed oxides }\end{array}$ \\
\hline $\begin{array}{l}\text { V2 } 1.2 \_24 h \\
\text { N2 } 1.2 \_24 h\end{array}$ & $\begin{array}{c}\mathrm{V}_{2} \mathrm{O}_{5} \\
\mathrm{NH}_{4} \mathrm{VO}_{3}\end{array}$ & Oxalic acid & & & & $\begin{array}{l}\text { Mixed oxides } \\
\text { Mixed oxides }\end{array}$ \\
\hline $\mathrm{V} 3{ }_{1.7 \_} 24 \mathrm{~h}$ & $\mathrm{~V}_{2} \mathrm{O}_{5}$ & Oxalic acid & 1:1.7:605 & 160 & 24 & Mixed oxides \\
\hline $\begin{array}{l}\mathrm{V} 4_{1.7} 6 \mathrm{~h} \\
\mathrm{~V} 51.7 \_8 \mathrm{~h} \\
\mathrm{~V} 6{ }_{1.7} 12 \mathrm{~h} \\
\mathrm{~V} 71.7 \_24 \mathrm{~h}\end{array}$ & $\mathrm{~V}_{2} \mathrm{O}_{5}$ & Oxalic acid & 1:1.7:605 & 180 & $\begin{array}{c}6 \\
8 \\
12 \\
24\end{array}$ & $\begin{array}{c}\mathrm{V}_{6} \mathrm{O}_{13} \\
\mathrm{~V}_{6} \mathrm{O}_{13} \\
\mathrm{VO}_{2}(\mathrm{~B}) \\
\mathrm{VO}_{2}(\mathrm{~B})\end{array}$ \\
\hline $\begin{array}{l}\text { V8 } 1.7 \_12 \mathrm{~h} \\
\mathrm{~V} 91.7 \_12 \mathrm{~h} \\
\text { V10 } 1.7 \_12 \mathrm{~h} \\
\text { V11 } 1.7 \_12 \mathrm{~h} \\
\mathrm{~V} 12_{1.7} 12 \mathrm{~h} \\
\mathrm{~V} 13_{1.7} 12 \mathrm{~h}\end{array}$ & $\mathrm{~V}_{2} \mathrm{O}_{5}$ & Oxalic acid & $\begin{array}{l}1: 1.7: 605 \\
1: 1.7: 509 \\
1: 1.7: 424 \\
1: 1.7: 364 \\
1: 1.7: 318 \\
1: 1.7: 282\end{array}$ & 180 & 12 & $\mathrm{VO}_{2}(\mathrm{~B})$ \\
\hline
\end{tabular}

First, the influence of two different vanadium precursors, i.e., $\mathrm{V}_{2} \mathrm{O}_{5}$ and $\mathrm{NH}_{4} \mathrm{VO}_{3}$, and two different reducing agents, i.e., oxalic acid and citric acid, was investigated, while the molar ratio between the vanadium precursor, the reducing agent, and the solvent was held constant. The temperature was set at $160{ }^{\circ} \mathrm{C}$ and the reaction was performed for $24 \mathrm{~h}$. The $\mathrm{V} 1_{1.2} \_24 \mathrm{~h}, \mathrm{~N} 1_{1.2} \_24 \mathrm{~h}, \mathrm{~V} 2_{1.2} \_24 \mathrm{~h}$, and $\mathrm{N} 2_{1.2} \_24 \mathrm{~h}$ samples were first investigated through XRD analysis in order to assess their crystalline phases. Figure $\mathrm{S} 1$ shows the X-ray diffractograms, showing an overlap of patterns deriving from a combination of different vanadium oxides (i.e., $\mathrm{V}_{2} \mathrm{O}_{3}, \mathrm{~V}_{4} \mathrm{O}_{7}, \mathrm{~V}_{6} \mathrm{O}_{13}, \mathrm{~V}_{3} \mathrm{O}_{7}$ ). Because these samples did not fulfil the aim of this work, they were not investigated further. Subsequently, the influence of the molar ratio of vanadium precursor/reducing agent $(\mathrm{V} / \mathrm{R})$ was screened by increasing the concentration of the reducing agent from 1:1.2 to 1:1.7 [25], as shown in the sample $\mathrm{V} 3_{1.7} 24 \mathrm{~h}$. This resulted in a mixed-oxide crystalline phase comparable to the $\mathrm{V} 2_{1.2} 24 \mathrm{~h}$ sample, as reported in Figure S2, probably ascribable to the low temperature of $160^{\circ} \mathrm{C}$. Subsequently, since the nature of both the vanadium precursor and reducing agent and the molar ratio $\mathrm{V} / \mathrm{R}$ were proven to not affect the crystalline phase of the samples, the effect of the temperature was additionally investigated, based on the phase diagram of the $\mathrm{VO}_{\mathrm{x}}$ system reported by Yang et al. [26]. It is known that vanadium cations $\mathrm{V}^{\mathrm{n}+}$ can display multiple valence states, leading to issues related to their stabilization. While maintaining a constant molar ratio between $\mathrm{V}_{2} \mathrm{O}_{5}$, oxalic acid, and the solvent, the temperature was increased to $180^{\circ} \mathrm{C}$ and the reaction time was systematically varied from $6 \mathrm{~h}$ to $24 \mathrm{~h}$, in 
order to identify the best temperature and time required for the synthesis of pure $\mathrm{VO}_{2}(\mathrm{~B})$, according to the cost-effectiveness requirement. Figure 1 reports the superimposition of the XRD.

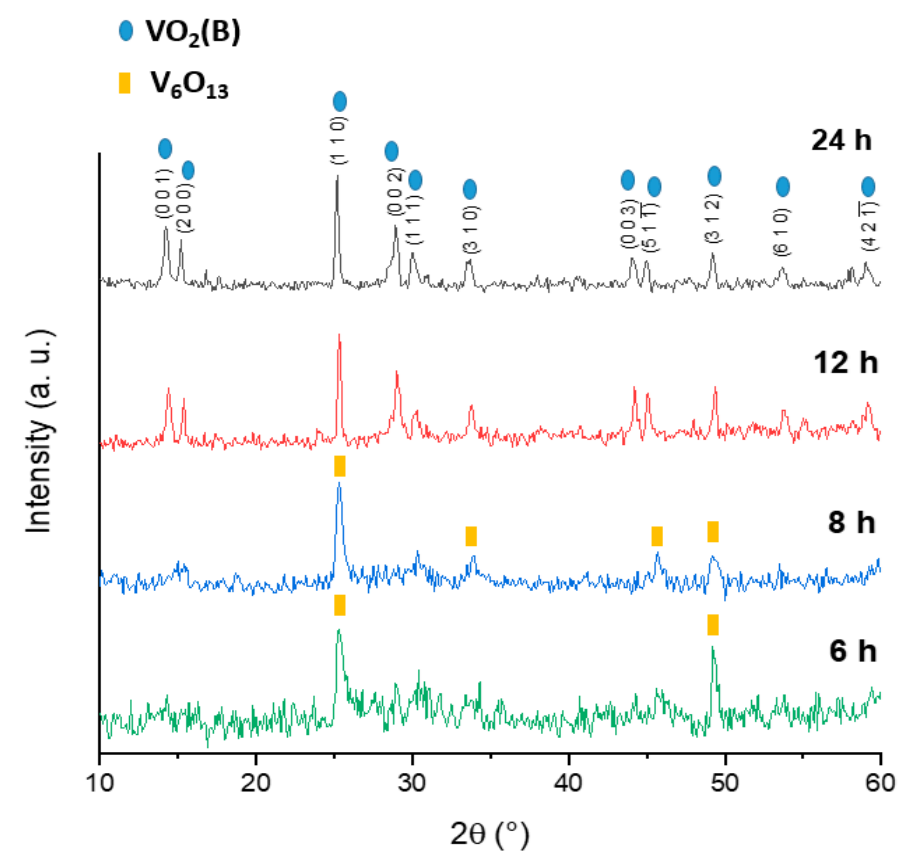

Figure 1. Superimposition of the XRD of the following samples: V4 $1.7 \_24 h$, V5 ${ }_{1.7} \_12 h, V 6_{1.7} 8 \mathrm{~h}$, V71.7_6h (Cu anode).

It is worth noting that $180^{\circ} \mathrm{C}$ and $12 \mathrm{~h}$ are, respectively, the minimum temperature and minimum reaction time required for the formation of the phase-pure crystalline monoclinic phase of $\mathrm{VO}_{2}(\mathrm{~B})$ with space group $\mathrm{C} 2 / \mathrm{m}$, lattice parameters $\mathrm{a}=12.050 \AA, \mathrm{b}=3.693 \AA$, $c=6.418, \alpha=90^{\circ}, \beta=106.88^{\circ}, \gamma=90^{\circ}$ (ICDD database pattern 01-081-2392). The X-ray diffraction patterns obtained at different reaction times, show that after $12 \mathrm{~h}$ the vanadium dioxide resulted in a highly crystalline pure phase of metastable $\mathrm{VO}_{2}(\mathrm{~B})$, showing relevant Bragg peaks at $14.1^{\circ}(001), 15.2^{\circ}(200), 28.9^{\circ}(002), 30.0^{\circ}(111)$, and $33.7^{\circ}(310)$ that were not present in the samples after $6 \mathrm{~h}$ and $8 \mathrm{~h}$, and a strong diffraction peak at $25.2^{\circ}(110)$ visible in every sample. No traces of other phases or impurities were detected after $12 \mathrm{~h}$ and $24 \mathrm{~h}$. The XRD of the sample after $24 \mathrm{~h}$ was comparable to the one after $12 \mathrm{~h}$, whereas upon further reducing the reaction time it was possible to observe the presence of only Bragg peaks at $25.2^{\circ}(110)$ and $49.2^{\circ}(312)$, related to $\mathrm{V}_{6} \mathrm{O}_{13}$, space group $\mathrm{C} 2 / \mathrm{m}$. The samples treated for 6 and $8 \mathrm{~h}$ displayed only the reflections related to planes (110) and (312), which were in agreement with the formation of the oxide $\mathrm{V}_{6} \mathrm{O}_{13}$. Since the synthesis involves the reduction of $\mathrm{V}_{2} \mathrm{O}_{5}$ (in which the vanadium species displays an oxidation state of $5+$ ) to $\mathrm{VO}_{2}$ (in which the oxidation state is $4+$ ), $\mathrm{V}_{6} \mathrm{O}_{13}$ represents an intermediate crystalline phase in which vanadium atoms display an average oxidation state of 4.3. Therefore, by increasing the reaction time, vanadium is completely reduced from $\mathrm{V}^{5+}$ to $\mathrm{V}^{4+}$. The apparent mean crystallite size in the direction perpendicular to the (110) plane, resulting in $\mathrm{D}=29.0 \pm 7.3 \mathrm{~nm}$ and $\mathrm{D}=30.1 \pm 6.7 \mathrm{~nm}$ after $12 \mathrm{~h}$ and $24 \mathrm{~h}$, respectively, shows that reaction times over $12 \mathrm{~h}$ did not affect the crystallite size. The Scherrer equation was employed, as reported below (1).

$$
\beta=\frac{\mathrm{K} \cdot \lambda}{\mathrm{D} \cdot \cos \theta}
$$

where $\mathrm{K}=0.94$ is the shape factor, $\lambda=1.54 \AA$ is the $\mathrm{X}$-ray wavelength, $\mathrm{D}=$ crystallite size $(\mathrm{nm}), \theta=$ Bragg angle $\left(^{\circ}\right)$.

Furthermore, it is possible to point out that upon increasing the reaction time from $6 \mathrm{~h}$ to $12 \mathrm{~h}$, sharper (110) and (312) reflections were observed, leading to the assumption 
of growth of the crystallite size. In order to investigate the morphology of the samples and to evaluate whether the reaction time affected the behavior of vanadium dioxide, SEM measurements were performed on $\mathrm{V}_{1.7} 24 \mathrm{~h}, \mathrm{~V} 5_{1.7} \_12 \mathrm{~h}, \mathrm{~V} 66_{1.7} \_\mathrm{h}$, and $\mathrm{V} 7_{1.7} 6 \mathrm{~h}$ samples, as displayed in Figure 2.

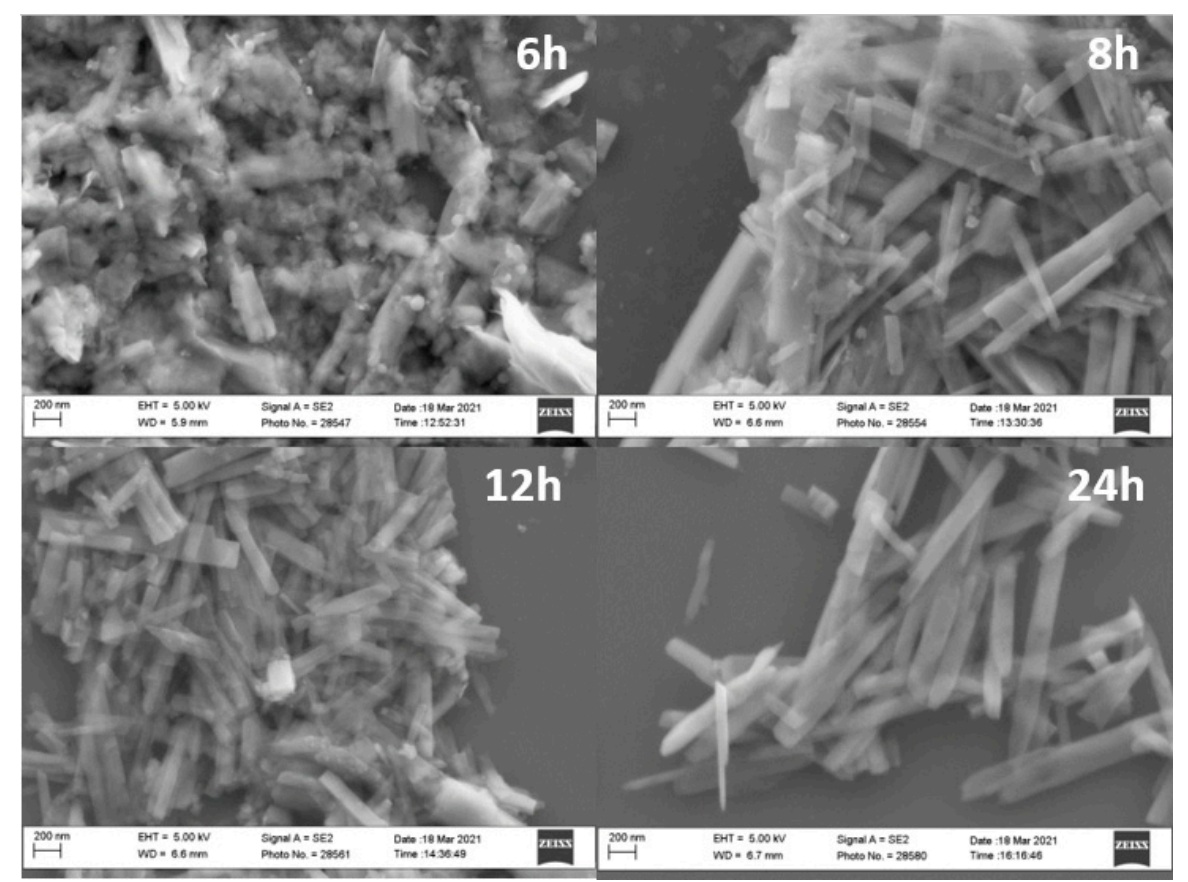

Figure 2. SEM measurements of the following samples: V4 $1.7 \_6 h, V 5_{1.7}$ 8h, V6 $1.7 \_12 \mathrm{~h}, \mathrm{~V} 7_{1.7}$ 24h, labeled as $6 \mathrm{~h}, 8 \mathrm{~h}, 12 \mathrm{~h}$, and $24 \mathrm{~h}$ respectively.

It is worth noting that a modification of the morphology of vanadium dioxide was observed in relation to the systematic variation of the reaction time. For each sample, 300 nanoparticles were analyzed in order to measure the average length and width of the as-obtained $\mathrm{VO}_{2}(\mathrm{~B})$ rod-like structures. These structures appeared more regular after $24 \mathrm{~h}$, while after $6 \mathrm{~h}$, no defined shape could be observed. After $8 \mathrm{~h}$ and $12 \mathrm{~h}$, the particles had the same average length and width, i.e., $651 \pm 104 \mathrm{~nm}$ and $401 \pm 38 \mathrm{~nm}$, respectively, whereas after $24 \mathrm{~h}$, the rod-like structures appeared longer and more regular, with an average length and width of $1136 \pm 127 \mathrm{~nm}$ and $407 \pm 41 \mathrm{~nm}$, respectively. While the widths of the $\mathrm{V} 51_{1.7} 8 \mathrm{~h}, \mathrm{~V} 6_{1.7}$ 12h, and $\mathrm{V7} 7_{1.7} 24 \mathrm{~h}$ samples did not increase upon increasing the reaction time, the length doubled. Therefore, since the aim of the synthesis was to obtain a pure $\mathrm{VO}_{2}(\mathrm{~B})$ crystalline phase without any specific morphology requirement, the $\mathrm{V} 6_{1.7}$ - $12 \mathrm{~h}$ sample was selected for the following thermal conversion to the $\mathrm{VO}_{2}(\mathrm{M} 1)$ polymorph.

\subsection{Conversion of $\mathrm{VO}_{2}(B)$ to $\mathrm{VO}_{2}(\mathrm{M} 1)$ Polymorph}

The $\mathrm{VO}_{2}(\mathrm{~B})$ polymorph structure consists of $\mathrm{VO}_{6}$ octahedral units joined by edges to form strings, which are connected by corners to give a three-dimensional structure. $\mathrm{VO}_{2}(\mathrm{M} 1)$ displays the same symmetry as the $\mathrm{VO}_{2}$ (B) polymorph except for the orientations of the oxygen octahedra, in which their 4-fold axes are aligned along two perpendicular planes [27]. In order to identify the optimal temperature required for the whole conversion of the $\mathrm{VO}_{2}(\mathrm{~B})$ polymorph into the $\mathrm{VO}_{2}(\mathrm{M} 1)$ structure, a temperature-dependent XRD analysis was performed on the $\mathrm{V}_{1.7}{ }_{1} 12 \mathrm{~h}$ sample. Figure 3 shows the superimposition of the X-ray patterns from $25^{\circ} \mathrm{C}$ to $700{ }^{\circ} \mathrm{C}$. Since the metal-insulator transition occurred at $68^{\circ} \mathrm{C}$ [14], the $\mathrm{VO}_{2}(\mathrm{M} 1)$ polymorph existed at low temperature, while the $\mathrm{VO}_{2}(\mathrm{R})$ crystal structure was present at temperatures higher than $68^{\circ} \mathrm{C}$, as can be seen from the XRD at $600{ }^{\circ} \mathrm{C}$ and $700{ }^{\circ} \mathrm{C}$. 


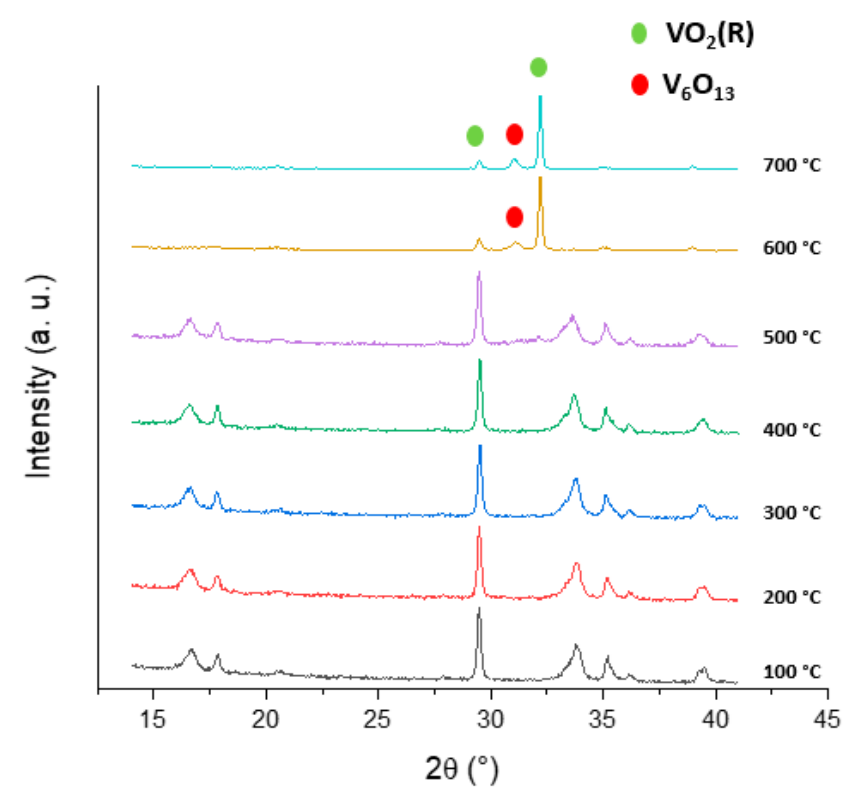

Figure 3. Superimposition of the temperature-dependent XRD patterns of the V5 1.7 12h sample (Co anode).

It is worth noting that up to $500^{\circ} \mathrm{C}$, the $\mathrm{XRD}$ displayed the reflections of pure $\mathrm{VO}_{2}(\mathrm{~B})$, while at $600{ }^{\circ} \mathrm{C}$, the pattern matched well with the $\mathrm{VO}_{2}(\mathrm{R})$ phase, with a small amount of the oxidized phase $\mathrm{V}_{6} \mathrm{O}_{13}$. Building on the data obtained from the temperature-dependent $\mathrm{XRD}$ analyses, the sample $\mathrm{V} 66_{1.7} 12 \mathrm{~h}$ was annealed in a furnace in order to induce the formation of the $\mathrm{VO}_{2}(\mathrm{M} 1)$ crystalline phase by varying the temperature and the reaction time, as reported in Table 2. The temperature was increased from $550{ }^{\circ} \mathrm{C}$ up to $700{ }^{\circ} \mathrm{C}$ and the time was varied from $2 \mathrm{~h}$ to $4.5 \mathrm{~h}$ under nitrogen to avoid the formation of the $\mathrm{V}_{6} \mathrm{O}_{13}[28]$ phase.

Table 2. Annealing at different temperatures and times for the conversion of $\mathrm{VO}_{2}(\mathrm{~B})$ to $\mathrm{VO}_{2}(\mathrm{M} 1)$.

\begin{tabular}{ccc}
\hline Sample & Temperature $\left({ }^{\circ} \mathbf{C}\right)$ & Time (h) \\
\hline & 550 & 2 \\
V5 $1.7 \_12 h$ & 550 & 4.5 \\
& 650 & 4.5 \\
& 700 & 4.5 \\
& 700 & 2 \\
\hline
\end{tabular}

Figure 4 shows the superimposition of the patterns of $\mathrm{V} 5_{1.7} \_12 \mathrm{~h}$ treated at $550{ }^{\circ} \mathrm{C}$ and at $700{ }^{\circ} \mathrm{C}$.

The mechanism involved in the conversion of $\mathrm{VO}_{2}(\mathrm{M} 1)$ to $\mathrm{VO}_{2}(\mathrm{R})$ has always been a very controversial topic, since the lattice distortion that causes the MIT has not yet been clarified [21]. Two mechanisms have been proposed, the Peierls and Mott-Hubbard models. The first is linked to an electron-lattice interaction [26] that arises from a lattice structural change in the material that causes a band structure change, and the second is related to an electron-electron interaction [29] that is often induced by temperature. Vanadium dioxide exhibits the possible formation of three different polymorphs during the reversible conversion from $\mathrm{VO}_{2}(\mathrm{M})$ to $\mathrm{VO}_{2}(\mathrm{R})$, i.e., $\mathrm{VO}_{2}(\mathrm{M} 1), \mathrm{VO}_{2}(\mathrm{~T})$, and $\mathrm{VO}_{2}(\mathrm{M} 2)$, as a consequence of the potential presence of strain within the crystal structure [22]. In particular, in the M1 phase, the $\mathrm{V}^{4+}$ atoms are paired and tilted, forming zigzag chains along the $\mathrm{c}_{\mathrm{R}}$ axis. In contrast, the $\mathrm{VO}_{2}(\mathrm{M} 2)$ polymorph has two distinct sublattices of vanadium atoms: in sublattice $A$, the $\mathrm{V}^{4+}$ atoms are paired but not tilted along the $c_{R}$ axis, and in sublattice $B$ they are tilted perpendicular to the $\mathrm{c}_{\mathrm{R}}$ axis but unpaired [22]. Aside from that, $\mathrm{VO}_{2}(\mathrm{M} 1)$ was the most prevalent polymorph obtained during the transition. It has a distorted rutile 
structure, in which the band structure comprises $\mathrm{V}_{3 \mathrm{~d}}$ and $\mathrm{O}_{2 \mathrm{p}}$ orbitals. $\mathrm{O}_{2 \mathrm{p}}$ orbitals are located at $2.5 \mathrm{eV}$ below the Fermi level and include $\sigma$ and $\pi$ bonds, while vanadium cations $\mathrm{V}^{4+}$ provide $3 \mathrm{~d}$ orbitals that are split into triply degenerate $t_{2 g}$ states, i.e., $d_{x z}, d_{x y}, d_{y z}$, and doubly degenerate $e_{g}$ states, i.e., $d_{x^{2}-y^{2}}, d_{z^{2}}$, which are placed at higher energy compared to the $t_{2 g}$ orbitals. The crystal field theory predicts the splitting of $t_{2 g}$ orbitals into $d_{\|}$and $\pi^{*}$; due to the $\mathrm{V}-\mathrm{V}$ twisting, in the monoclinic M1 phase, the $d_{\|}$band is split into two energy bands, i.e., $d_{\|}$and $d_{\|}^{*}$, and a forbidden band is formed between them of nearly $0.7 \mathrm{eV}$. The Fermi level lies between the $d_{\|}$and the $\pi^{*}$ orbitals causing insulator behavior. In contrast, in the rutile phase, the Fermi level of the $\mathrm{VO}_{2}(\mathrm{R})$ polymorph lies between the $d_{\| 1}$ and the $\pi^{*}$ bands, showing metallic behavior [22]. During the transition from to $\mathrm{VO}_{2}(\mathrm{M} 1)$ to $\mathrm{VO}_{2}(\mathrm{R})$, a charge in the crystal lattice occurs, inducing the switch from a low-symmetry monoclinic structure to a high-symmetry tetragonal structure. In the $\mathrm{VO}_{2}(\mathrm{R})$ polymorph, the distance between two nearest $\mathrm{V}-\mathrm{V}$ is $2.85 \AA$, while in the $\mathrm{VO}_{2}(\mathrm{M} 1)$ crystal structure $\mathrm{V}-\mathrm{V}$ bonds with different lengths are formed. The longest distance is $3.19 \AA$ and the shortest is $2.60 \AA$. Figure 5 shows the comparison between the structures of $\mathrm{VO}_{2}(\mathrm{~B}), \mathrm{VO}_{2}(\mathrm{M} 1)$, and $\mathrm{VO}_{2}(\mathrm{R})$ polymorphs.

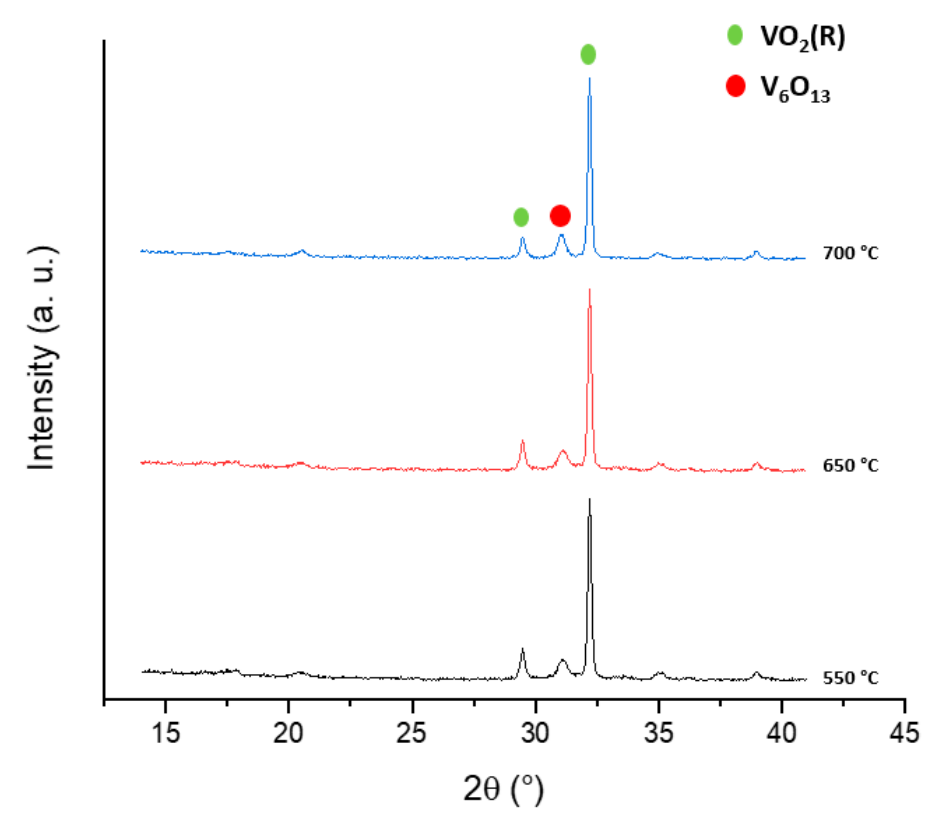

Figure 4. Superimposition of the XRD patterns of $\mathrm{V} 5_{1.7}$ - $12 \mathrm{~h}$ sample annealed at $550{ }^{\circ} \mathrm{C}, 650{ }^{\circ} \mathrm{C}$, and $700{ }^{\circ} \mathrm{C}$ (Co anode).
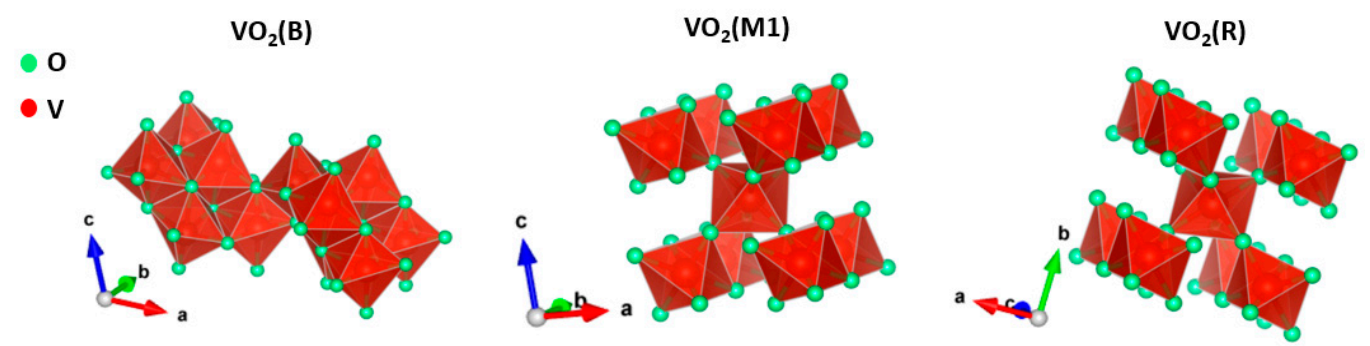

Figure 5. Comparison between the structures of $\mathrm{VO}_{2}(\mathrm{~B}), \mathrm{VO}_{2}(\mathrm{M} 1)$, and $\mathrm{VO}_{2}(\mathrm{R})$.

Since the MIT is reported in the literature to occur at $68{ }^{\circ} \mathrm{C}$, a temperature-dependent $\mathrm{XRD}$ analysis was carried out in the range of $25^{\circ} \mathrm{C}$ to $150^{\circ} \mathrm{C}$ to identify the temperature of the transition from the obtained $\mathrm{VO}_{2}(\mathrm{M} 1)$ to $\mathrm{VO}_{2}(\mathrm{R})$, as reported in Figure 6 . 

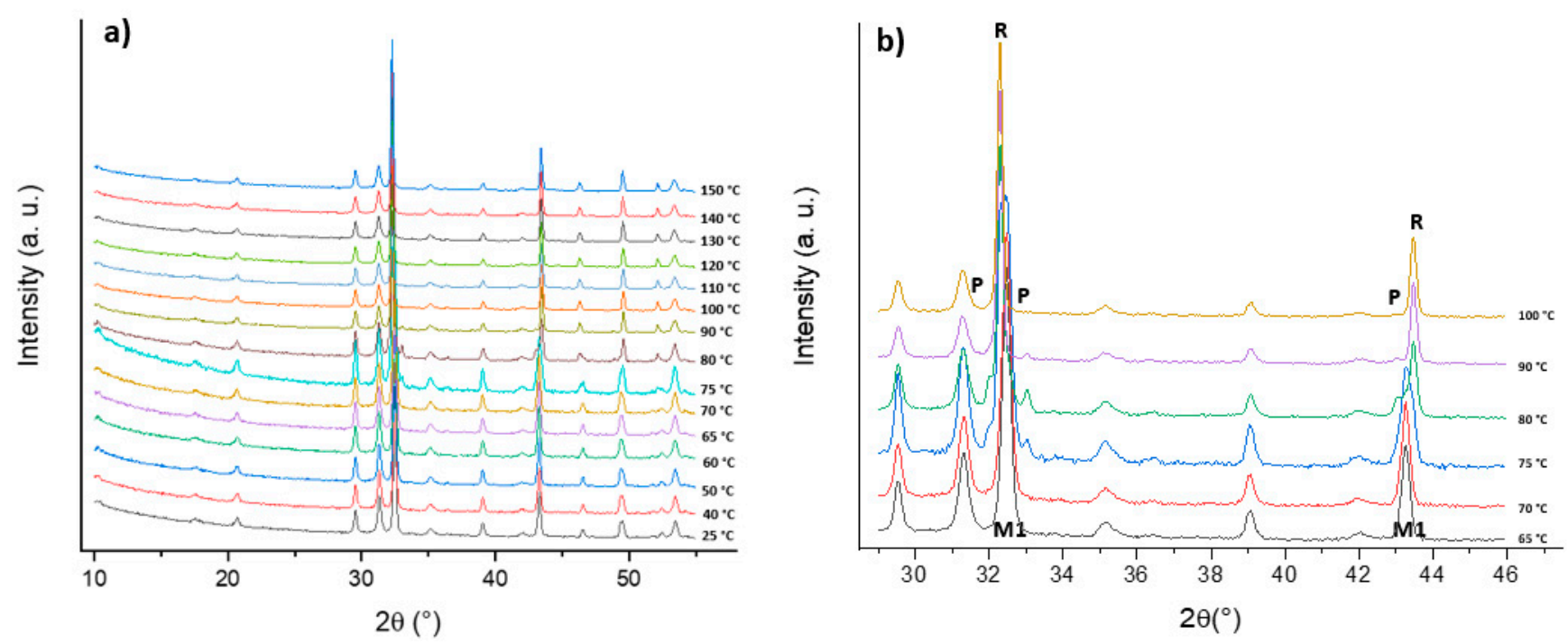

Figure 6. Overlap of the temperature-dependent $\mathrm{XRD}$ analysis from $25^{\circ} \mathrm{C}$ to $150{ }^{\circ} \mathrm{C}$ (a), and a focus from $65{ }^{\circ} \mathrm{C}$ to $100{ }^{\circ} \mathrm{C}$ and from to $29^{\circ}(2 \theta)$ to $46^{\circ}(2 \theta)(\mathbf{b})$. The crystalline phases are labeled in (b) as M1, R, and $\mathrm{P}$ for $\mathrm{VO}_{2}(\mathrm{M} 1), \mathrm{VO}_{2}(\mathrm{R})$, and $\mathrm{VO}_{2}(\mathrm{P})$, respectively (Co anode).

The metal-insulator transition was revealed by a shift of two Bragg reflections belonging to $\mathrm{VO}_{2}(\mathrm{M} 1)$ : the first at $32.5^{\circ}$ underwent a shift to a lower angle (from $32.5^{\circ}$ to $32.3^{\circ}$ ), while the reflection at $43.3^{\circ}$ underwent a shift to a higher angle (from $43.4^{\circ}$ to $43.5^{\circ}$ ). During the MIT, the formation of an orthorhombic phase, an additional polymorph known as $\mathrm{VO}_{2}(\mathrm{P})[20]$ and labeled as $\mathrm{P}$ in Figure $6 \mathrm{~b}$, was observed. This species appeared during the conversion from $\mathrm{VO}_{2}(\mathrm{M} 1)$ to $\mathrm{VO}_{2}(\mathrm{R})$ and disappeared when the transition was completed. Therefore, the thermal conversion of the monoclinic vanadium dioxide to the tetragonal crystal structure occurred over a broad range between $65^{\circ} \mathrm{C}$ and $100{ }^{\circ} \mathrm{C}$. Since the reversible conversion from $\mathrm{VO}_{2}(\mathrm{M} 1)$ to $\mathrm{VO}_{2}(\mathrm{R})$ is a fundamental characteristic of vanadium dioxide, DSC analysis was carried out in order to identify the actual temperature of the phase transition (Figure 7).

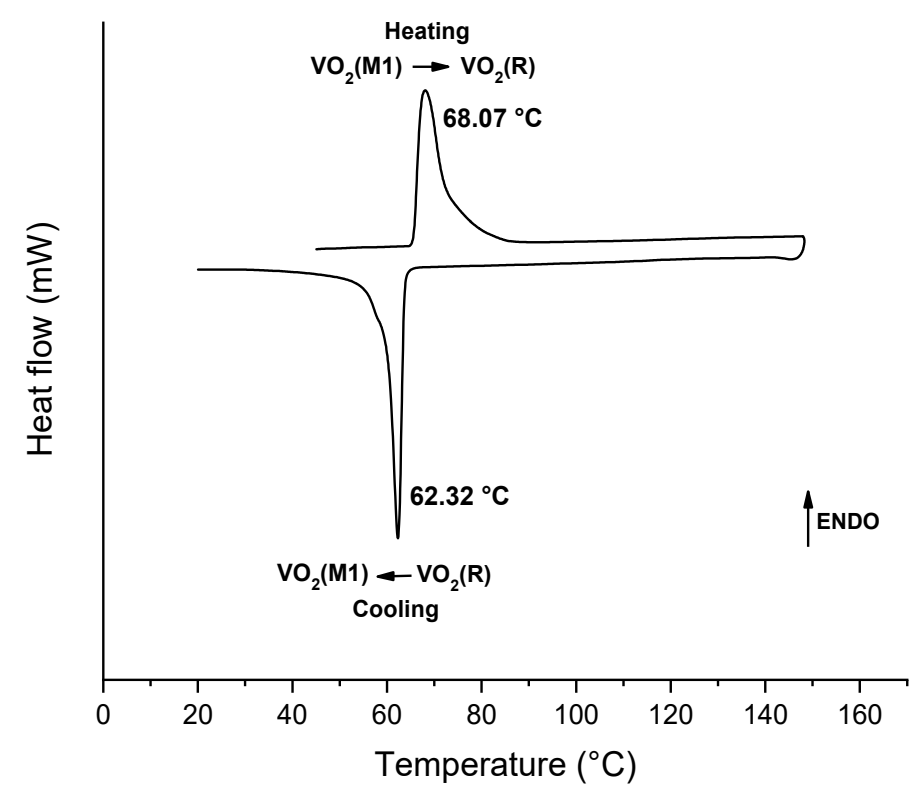

Figure 7. DSC curve of $\mathrm{V} 61_{1.7} 12 \mathrm{~h}$ sample over two heating and cooling cycles, where $68.07^{\circ} \mathrm{C}$ and $62.32{ }^{\circ} \mathrm{C}$ were the temperatures of the phase transitions $\mathrm{VO}_{2}(\mathrm{M}) \rightarrow \mathrm{VO}_{2}(\mathrm{R})$ and $\mathrm{VO}_{2}(\mathrm{M}) \rightarrow \mathrm{VO}_{2}(\mathrm{R})$, respectively. 
As can be seen, the two phase transitions (M1) $\rightarrow(\mathrm{R})$ and $(\mathrm{R}) \rightarrow(\mathrm{M} 1)$ occurred at $68.1{ }^{\circ} \mathrm{C}$ and $62.3^{\circ} \mathrm{C}$, respectively, and the transition enthalpies $\left(\Delta \mathrm{H}_{\mathrm{T}}\right)$ associated with the conversions were $2.8 \mathrm{~kJ} / \mathrm{mol}$ and $-2.7 \mathrm{~kJ} / \mathrm{mol}$ during the heating and cooling cycles, respectively. In particular, the phase transition (M1) $\rightarrow$ (R) consists of an endothermic phenomenon, while the $(\mathrm{R}) \rightarrow(\mathrm{M} 1)$ transition involves an exothermic phenomenon, according to the literature [30]. The peaks show some broadening and a shoulder is apparent, specifically at about $55^{\circ} \mathrm{C}$ in the cooling exotherm. This can probably be ascribed to the polydispersity in the size of crystals, supported by the SEM images in Figure 2.

\subsection{Functionalization of $\mathrm{VO}_{2}(\mathrm{M1})$ with a Silica Layer}

Since the $\mathrm{VO}_{2}(\mathrm{M} 1)$ could be applied for possible use in dynamic concrete, a functionalization with TEOS to produce a silica coating was carried out, with the purpose of increasing the compatibility between the inorganic powder and the concrete itself. This coating was optimized for the $V 5_{1.7} \_12 \mathrm{~h}$ sample after annealing treatment at $700{ }^{\circ} \mathrm{C}$. The literature regarding this functionalization procedure is not extensive. Some works, reported by Zhu et al. [31] and Zhe at al. [32], describe a functionalization route aimed at coating $\mathrm{VO}_{2}$ nanoparticles with silica using TEOS as a precursor. In our work, TEM analysis was employed in order to detect the presence of the $\mathrm{SiO}_{2}$ layer, as reported in Figure 8.

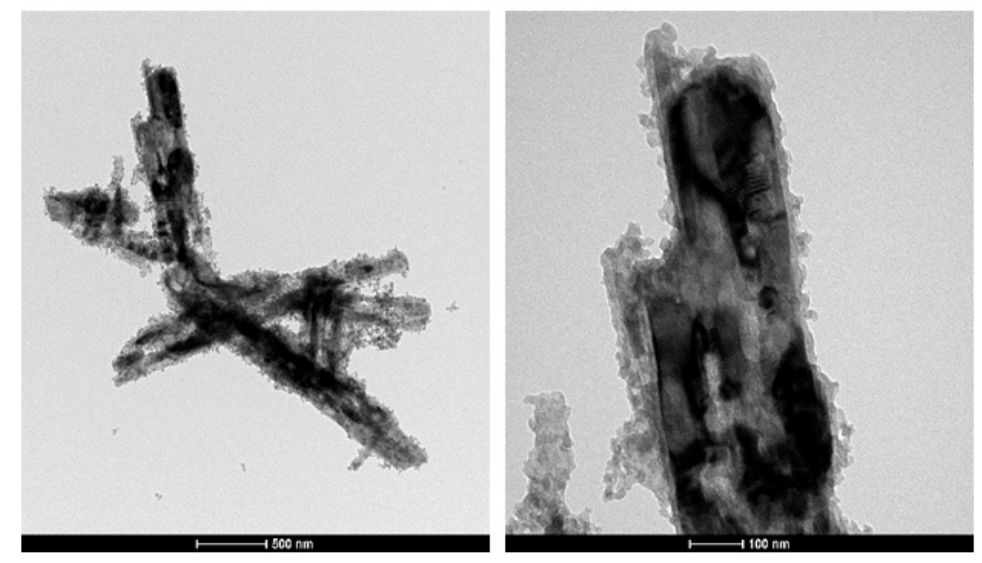

Figure 8. TEM images of $\mathrm{V}_{1}$ 1.7_12h sample (the black rod-like structures) functionalized with a $\mathrm{SiO}_{2}$ layer (the grey globular layer).

The amorphous and globular layer around the rod-like crystals of vanadium dioxide was ascribed to the presence of the $\mathrm{SiO}_{2}$, with a thickness up to $30 \mathrm{~nm}$. The coating seemed to be homogeneously distributed on the surface of $\mathrm{VO}_{2}$ crystals. In order to verify the homogeneity of the functionalization around the vanadium dioxide particles, a SEM-EDX analysis was carried out, as reported in Figure 9.
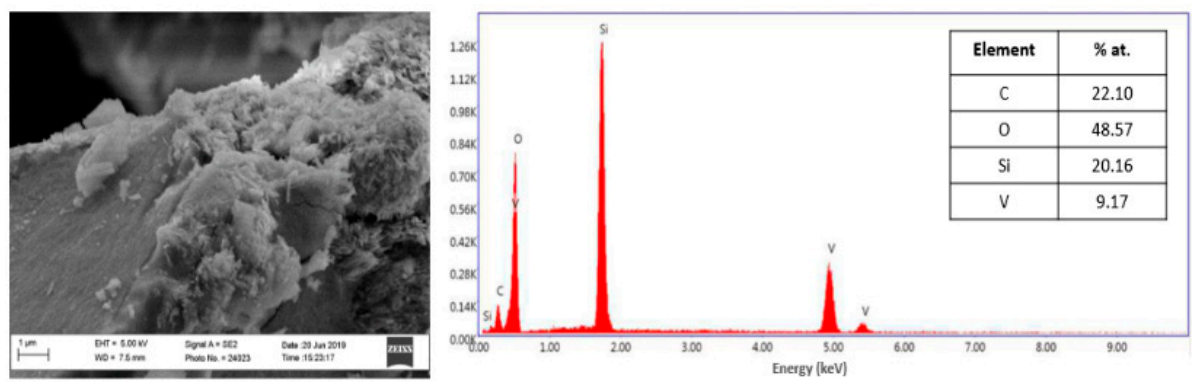

Figure 9. SEM-EDX analysis on V51.7_12h sample functionalized with silica.

The energy dispersive X-ray (EDX) analysis provided additional insight into the composition of the surface of vanadium dioxide coated with the silica layer. The results 
confirmed the presence of vanadium $(\mathrm{V})$, oxygen $(\mathrm{O})$, and silicon $(\mathrm{Si})$ elements, in particular with an atomic ratio $\mathrm{Si} / \mathrm{V}$ of 2.2, in agreement with the ratio employed in the synthesis. Subsequently, since the $\mathrm{pH}$ of concrete is around $\mathrm{pH}=11$, after the incorporation of clinker, the stability of the functionalized $\mathrm{V}_{1.7}{ }_{12} \mathrm{~h}$ sample under alkaline $\mathrm{pH}$ was evaluated by suspending $100 \mathrm{mg}$ of powder in a $\mathrm{Ca}(\mathrm{OH})_{2}$ solution under vigorous stirring. After $24 \mathrm{~h}$, an XRD analysis was carried out, which did not show the formation of any additional crystalline phases, as reported in Figure S3; therefore, the functionalized vanadium dioxide can be used for possible embedding into a concrete matrix. Additionally, a scale-up process was implemented in order to increase the amount of $\mathrm{VO}_{2}(\mathrm{~B})$ obtained from the hydrothermal synthesis. With this purpose, the concentration of the vanadium precursor and the reducing agent was increased while the $\mathrm{V}_{2} \mathrm{O}_{5}$ / oxalic acid molar ratio was kept constant. XRD measurements were employed in order to exclude the formation of other crystalline phases beyond the $\mathrm{VO}_{2}(\mathrm{~B})$, and these confirmed the phase purity of monoclinic vanadium dioxide.

\section{Materials and Methods}

Vanadium (V) pentoxide $\left(\mathrm{V}_{2} \mathrm{O}_{5}, 98 \%\right)$ and ammonium metavanadate $(\mathrm{V})\left(\mathrm{NH}_{4} \mathrm{VO}_{3}\right.$, $99.9 \%$ ) were employed as precursors for the synthesis of vanadium dioxide, while oxalic acid $(98 \%)$ and citric acid monohydrate $(\geq 99 \%)$ were used as reducing agents. Deionized water was employed as the solvent. Ammonium hydroxide solution $(33 \% \mathrm{~h})$, tetraethyl orthosilicate (TEOS), and absolute ethanol (99\%) were employed for the functionalization procedure, while $\mathrm{Ca}(\mathrm{OH})_{2}$ was employed for the stability test in alkaline $\mathrm{pH}$. All reagents were purchased from Sigma-Aldrich.

\subsection{Hydrothermal Synthesis and Scale-Up Process}

A given amount of vanadium precursor $\left(\mathrm{V}_{2} \mathrm{O}_{5}\right.$ or $\left.\mathrm{NH}_{4} \mathrm{VO}_{3}\right)$ and of reducing agent (oxalic acid or citric acid) were added to $10 \mathrm{~mL}$ of deionized water in a molar ratio of 1:1.2 and 1:1.7 vanadium precursor/reducing agent, and placed in a $23 \mathrm{~mL}$ A255AC PTFE cup with constant stirring. The solution was stirred for $20 \mathrm{~min}$ and then placed in a stainless steel 4745 General Purpose Acid-Digestion Bomb and heated at a set temperature, from $160^{\circ} \mathrm{C}$ to $180^{\circ} \mathrm{C}$, for a set time, from $6 \mathrm{~h}$ to $24 \mathrm{~h}$, in order to reduce the $\mathrm{V}_{2} \mathrm{O}_{5}\left(\mathrm{~V}^{5+}\right)$ to $\mathrm{VO}_{2}$ $\left(\mathrm{V}^{4+}\right)$, as reported in Equation (2) below:

$$
\mathrm{V}_{2} \mathrm{O}_{5}+\mathrm{H}_{2} \mathrm{C}_{2} \mathrm{O}_{4} \rightarrow 2 \mathrm{VO}_{2}+2 \mathrm{CO}_{2}+\mathrm{H}_{2} \mathrm{O}
$$

After cooling at room temperature, the resulting powder was washed three times with $5 \mathrm{~mL}$ of deionized water and once with $5 \mathrm{~mL}$ of ethanol and collected by centrifugation at $10,000 \mathrm{rpm}$ for $10 \mathrm{~min}$ before drying at $80^{\circ} \mathrm{C}$ in an oven for $6 \mathrm{~h}$. The synthesis was scaled up by increasing the concentrations of the precursors in the solution, therefore constantly decreasing the molar ratio with the solvent, and by using a $210 \mathrm{~mL}$ PTFE cup placed in a stainless steel Acid-Digestion Bomb. The prepared samples are summarized in the Results and Discussion section, described in detail in the supporting information in Table S1 and labeled in the paper as follows:

$\mathrm{Vx}_{\mathrm{y}} \mathrm{z}$, where $\mathrm{V}=\mathrm{V}_{2} \mathrm{O}_{5}$ precursor, $\mathrm{x}=$ number of the synthetized sample, $\mathrm{y}=\mathrm{V}_{2} \mathrm{O}_{5}$ : reducing agent molar ratio, $\mathrm{z}=$ reaction time

$\mathrm{Nx}_{\mathrm{y}} \mathrm{z}$, where $\mathrm{N}=\mathrm{NH}_{4} \mathrm{VO}_{3}$ precursor, $\mathrm{x}=$ number of the synthetized sample, $\mathrm{y}=\mathrm{NH}_{4} \mathrm{VO}_{3}$ : reducing agent molar ratio, $\mathrm{z}=$ reaction time

\subsection{Thermal Conversion of $\mathrm{VO}_{2}(B)$ to $\mathrm{VO}_{2}(\mathrm{M} 1)$}

The thermal treatment, that aimed at the conversion of $\mathrm{VO}_{2}(\mathrm{~B})$ into $\mathrm{VO}_{2}(\mathrm{M} 1)$, was carried out via annealing under pure nitrogen atmosphere in a tube furnace at a set temperature, from $550{ }^{\circ} \mathrm{C}$ to $700{ }^{\circ} \mathrm{C}$, for a set time, from $2 \mathrm{~h}$ to $4.5 \mathrm{~h}$, with a ramp of $5{ }^{\circ} \mathrm{C} / \mathrm{min}$. At the end, the powder was recovered and stored for further analysis. 


\subsection{Functionalization of $\mathrm{VO}_{2}(\mathrm{M} 1)$ with $\mathrm{SiO}_{2}$ Layer}

A given amount of $\mathrm{VO}_{2}(\mathrm{M} 1)$ powder was dispersed in an aqueous solution of $5 \mathrm{M}$ citric acid in a molar ratio of 1:1 and 1:4 $\mathrm{VO}_{2}(\mathrm{M}) /$ citric acid, and the $\mathrm{pH}$ value was then adjusted to $\mathrm{pH} 5$ with the addition of ammonium hydroxide solution $(33 \% w / w)$ under constant stirring for $2 \mathrm{~h}$. The $\mathrm{pH}$ was then increased to $\mathrm{pH} 10-11$ by adding $\mathrm{NH}_{3}$, and a solution of $0.045 \mathrm{M}$ tetraethyl orthosilicate (TEOS) in ethanol was added to the suspension. The mixture was stirred for a set time, from $16 \mathrm{~h}$ to $24 \mathrm{~h}$, to complete the hydrolysis and condensation of TEOS. The suspension was filtered, and the obtained powder was washed several times with deionized water to neutral $\mathrm{pH}$ and dried in the oven at $60{ }^{\circ} \mathrm{C}$ for $8 \mathrm{~h}$.

\subsection{Stability Tests at Alkaline $\mathrm{pH}$}

A given amount of $\mathrm{VO}_{2}(\mathrm{M} 1)$ functionalized with $\mathrm{SiO}_{2}$ was suspended in $30 \mathrm{~mL}$ of aqueous solution of $2 \mathrm{mM} \mathrm{Ca}(\mathrm{OH})_{2}$ at $\mathrm{pH}=11$ for $24 \mathrm{~h}$ under vigorous stirring at room temperature. The sample was allowed to dry in the oven at $90{ }^{\circ} \mathrm{C}$ for $6 \mathrm{~h}$.

\subsection{Characterizations of $\mathrm{VO}_{2}(B)$}

\subsubsection{X-ray Diffraction Analysis}

XRD patterns were collected with a Bruker D8 Advance diffractometer equipped with a Göbel mirror and employing a $\mathrm{Cu} \mathrm{K} \alpha$ radiation source. All patterns were recorded in the $10-60^{\circ}$ range with a $0.01^{\circ}(2 \theta)$ scan step and a $10 \mathrm{~s}$ per step acquisition time. The temperature dependent-XRD patterns were collected with a Panalytical X'Pert Pro diffractometer, equipped with a high-temperature chamber (ANTON PAAR HTK 16) and employing a Co $\mathrm{K}_{\alpha}$ radiation source. All patterns were recorded in the $14-41^{\circ}$ range with a $0.03^{\circ}(2 \theta)$ scan step and a $60 \mathrm{~s}$ per step acquisition time. Patterns were analyzed using HighScore Plus and EVA software in order to obtain the lattice parameters and the apparent mean crystallite sizes of the powders.

\subsubsection{SEM-EDX Analysis}

Field-emission scanning electron microscopy (FE-SEM) and energy-dispersive X-ray analysis (EDX) were run on a Zeiss SUPRA 40VP equipped with an Oxford INCA xsight $\mathrm{X}$-ray detector. Morphological analysis was carried out by setting the acceleration voltage at $5 \mathrm{kV}$, whereas the EDX compositional investigations were obtained by setting the acceleration voltage at $20 \mathrm{kV}$. Particle size analysis was carried out using the public domain software ImageJ (National Institute of Health, Bethesda, MD, USA). A total of 300 particles were analyzed to extract the width and length of the particles.

\subsubsection{TEM Analysis}

TEM micrographs were obtained with a FEI Tecnai G12 microscope operating at $100 \mathrm{kV}$, equipped with an OSIS Veleta camera. Samples were prepared by suspending the dried powders in MilliQ water through sonication and then depositing them on 300-mesh lacey carbon-coated copper grids.

\subsubsection{DSC Analysis}

All measurements were carried out with a model 2920 calorimeter (TA Instruments) operating in air. The samples, weighing about $5-7 \mathrm{mg}$, were closed in aluminum pans. A first heating ramp at $10^{\circ} \mathrm{C} / \mathrm{min}$ was used from $25^{\circ} \mathrm{C}$ up to $150^{\circ} \mathrm{C}$ and, after erasure of thermal history by a $5 \mathrm{~min}$ isotherm at $150^{\circ} \mathrm{C}$, the sample was cooled down to $25^{\circ} \mathrm{C}$ at $10^{\circ} \mathrm{C} / \mathrm{min}$ and heated again to $150^{\circ} \mathrm{C}$ at the same rate. High-purity indium was used to calibrate the DSC temperature and enthalpy scales.

\section{Conclusions}

In this study, the synthesis of pure vanadium dioxide $\mathrm{VO}_{2}(\mathrm{~B})$, its thermal conversion to $\mathrm{VO}_{2}(\mathrm{M} 1)$, and its further functionalization with a silica layer are reported. In particular, a pure crystalline phase of monoclinic $\mathrm{VO}_{2}(\mathrm{~B})$ was produced via a straightforward, repro- 
ducible, and scalable subcritical hydrothermal route, followed by an annealing process under nitrogen to induce the formation of the $\mathrm{VO}_{2}(\mathrm{M} 1)$ polymorph.

Compared to the syntheses reported in literature, our approach is easy, fast, costeffective, and uses no hazardous chemicals.

Using a combination of different analytical tools and based on XRD analyses, SEM, TEM, and EDX measurements for structural, morphological, and compositional characterization respectively, it was possible to confirm the purity of the crystalline phase, the size of the rod-like particles, and the presence of the silica layer. By varying the synthetic parameters in terms of vanadium precursor/reducing agent molar ratio, temperature, and reaction time, it was established that $12 \mathrm{~h}$ and $180{ }^{\circ} \mathrm{C}$ are the optimal time and temperature required for the formation of a pure crystalline phase of $\mathrm{VO}_{2}(\mathrm{~B})$, according to the requirements of high yield and a cost-effective process. The thermal conversion and subsequent functionalization with a silica layer were crucial to obtaining the desired thermochromic phase $\mathrm{VO}_{2}(\mathrm{M} 1)$ with enhanced stability in an alkaline environment, disclosing the possibility of its use in a concrete matrix for possible dynamic cooling effect. Furthermore, it is worth noting that the scale-up process, fundamental for future application in industrial processes, did not affect either the morphology or the purity of the crystalline phase, or the high stability of the vanadium dioxide in an alkaline environment.

Supplementary Materials: The following are available online, Table S1: Detailed list of the synthetized samples through hydrothermal route, Figure S1 XRD analyses of the following samples:

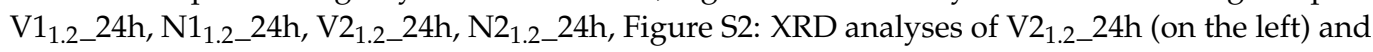
V3 $1.7 \_24$ h (on the right) with two different vanadium precursor/reducing agent molar ratios, e.g., 1:1.2 and 1:1.7 respectively, without showing any improving in the formation of the pure crystalline phase, Figure S3: XRD analyses before (black line) and after (red line) the stability test of vanadium dioxide by its suspension in an alkaline solution of $\mathrm{Ca}(\mathrm{OH})_{2}$ for $24 \mathrm{~h}$.

Author Contributions: Conceptualization, C.C., A.C., S.G.; methodology: E.P., A.C., G.B., C.C., S.G.; investigation, data curation, validation and formal analysis, G.B., F.Z., E.P., V.C.; writing and editing, G.B., C.C., S.G.; supervision, S.G. All authors have read and agreed to the published version of the manuscript.

Funding: This research was funded by Italcementi S.p.A., CUP number G16G16000690003.

Institutional Review Board Statement: Not applicable.

Informed Consent Statement: Not applicable.

Data Availability Statement: The data presented in this study are available within the paper and the Supplementary Information.

Acknowledgments: Giulia Bragaggia and Silvia Gross gratefully thank Italcementi S.p.A. for funding this project. We acknowledge Anna Cavinato from the East Oregon University for discussion and reading.

Conflicts of Interest: The authors declare no conflict of interest.

Sample Availability: All samples are available from the authors.

\section{References}

1. Granqvist, C.G. Solar Energy Materials for Thermal Applications. In Kirk-Othmer Encyclopedia of Chemical Technology; John Wiley \& Sons, Inc.: Hoboken, NJ, USA, 2017; pp. 1-28.

2. Baetens, R.; Jelle, B.P.; Gustavsen, A. Properties, requirements and possibilities of smart windows for dynamic daylight and solar energy control in buildings: A state-of-the-art review. Sol. Energy Mater. Sol. Cells 2010, 94, 87-105. [CrossRef]

3. Wang, Y.; Runnerstrom, E.L.; Milliron, D.J. Switchable Materials for Smart Windows. Annu. Rev. Chem. Biomol. Eng. 2016, 7, 283-304. [CrossRef] [PubMed]

4. Mott, N.F. Metal-Insulator Transition. Rev. Mod. Phys. 1968, 40, 677-683. [CrossRef]

5. Kanu, S.S.; Binions, R. Thin films for solar control applications. Proc. R. Soc. A Math. Phys. Eng. Sci. 2010, 466, 19-44. [CrossRef]

6. Kamalisarvestani, M.; Saidur, R.; Mekhilef, S.; Javadi, F.S. Performance, materials and coating technologies of thermochromic thin films on smart windows. Renew. Sustain. Energy Rev. 2013, 26, 353-364. [CrossRef] 
7. Lüthi, D.; Le Floch, M.; Bereiter, B.; Blunier, T.; Barnola, J.; Siegenthaler, U.; Raynaud, D.; Jouzel, H.; Kawamura, K.; Stocker, T. High-resolution carbon dioxide concentration record 650,000-800,000 years before present. Nature 2008, 453, 379-382. [CrossRef]

8. Alley, R.B. Abrupt Climate Change. Science 2003, 299, 2005-2010. [CrossRef]

9. Granqvist, C.G. Electrochromics and Thermochromics: Towards a New Paradigm for Energy Efficient Buildings. Mater. Today Proc. 2016, 3, S2-S11. [CrossRef]

10. Adler, D. Mechanisms for Metal-Nonmental Transitions in Transition-Metal Oxides and Sulfides. Rev. Mod. Phys. 1968, 40, 714-736. [CrossRef]

11. Torrance, J.; Lacorre, P.; Nazzal, A.; Ansaldo, E.; Niedermayer, C. Systematic study of insulator-metal transitions in perovskites $\mathrm{RNiO}_{3}(\mathrm{R}=\mathrm{Pr}, \mathrm{Nd}, \mathrm{Sm}, \mathrm{Eu})$ due to closing of charge-transfer gap. Phys. Rev. B 1992, 45, 8209-8212. [CrossRef]

12. Mjejri, I.; Rougier, A.; Gaudon, M. Low-Cost and Facile Synthesis of the Vanadium Oxides $\mathrm{V}_{2} \mathrm{O}_{3}, \mathrm{VO}_{2}$, and $\mathrm{V}_{2} \mathrm{O}_{5}$ and Their Magnetic, Thermochromic and Electrochromic Properties. Inorg. Chem. 2017, 56, 1734-1741. [CrossRef]

13. Babulanam, S.M.; Eriksson, T.S.; Niklasson, G.A.; Granqvist, C.G. Thermochromic $\mathrm{VO}_{2}$ films for energy-efficient windows. Sol. Energy Mater. 1987, 16, 347-363. [CrossRef]

14. Li, M.; Magdassi, S.; Gao, Y.; Long, Y. Hydrothermal Synthesis of $\mathrm{VO}_{2}$ Polymorphs: Advantages, Challenges and Prospects for the Application of Energy Efficient Smart Windows. Small 2017, 13, 1-25. [CrossRef] [PubMed]

15. Wang, Y.; Zhu, J.; Yang, W.; Wen, T.; Pravica, M.; Liu, Z.; Hou, M.; Fei, Y.; Kang, L.; Lin, Z.; et al. Reversible switching between pressure-induced amorphization and thermal-driven recrystallization in $\mathrm{VO}_{2}$ (B) nanosheets. Nat. Commun. 2016, 7, 12214. [CrossRef]

16. Wang, Q.; Jing, P.; Li, M.; Luo, Y.; Wu, H.; Zhong, L.; Li, G. VO 2 (B) Nanosheets as a Cathode Material for Li-ion Battery. J. Mater. Sci. Technol. 2015, 31, 630-633. [CrossRef]

17. Qu, B.Y.; Liu, L.; Xie, Y.; Pan, B.C. Theoretical study of the new compound $\mathrm{VO}_{2}$ (D). Phys. Lett. A 2011, 375, 3474-3477. [CrossRef]

18. Liu, L.; Cao, F.; Yao, T.; Xu, Y.; Zhou, M.; Qu, B.; Pan, B.; Wu, C.; Wei, S.; Xie, Y. New-phase $\mathrm{VO}_{2}$ micro/nanostructures: Investigation of phase transformation and magnetic property. New J. Chem. 2012, 36, 619-625. [CrossRef]

19. Zhang, Y.; Fan, M.; Niu, F.; Zhong, Y.; Huang, C.; Liu, X.; Wang, B.; Li, H. Hydrothermal synthesis of $\mathrm{VO}_{2}(\mathrm{~A})$ nanobelts and their phase transition and optical switching properties. Micro Nano Lett. 2011, 6, 888. [CrossRef]

20. Wu, C.; Hu, Z.; Wang, W.; Zhang, M.; Yang, J.; Xie, Y. Synthetic paramontroseite $\mathrm{VO}_{2}$ with good aqueous lithium-ion battery performance. Chem. Commun. 2008, 5, 3891. [CrossRef] [PubMed]

21. Wentzcovitch, R.M.; Schulz, W.W.; Allen, P.B. $\mathrm{VO}_{2}$ : Peierls or Mott-Hubbard? A view from band theory. Phys. Rev. Lett. 1994, 72, 3389-3392. [CrossRef] [PubMed]

22. Shao, Z.; Cao, X.; Luo, H.; Jin, P. Recent progress in the phase-transition mechanism and modulation of vanadium dioxide materials. NPG Asia Mater. 2018, 10, 581-605. [CrossRef]

23. Bretos, I.; Diodati, S.; Jiméenez, R.; Tajoli, F.; Ricote, J.; Bragaggia, G.; Franca, M.; Calzada, M.L.; Gross, S. Low-Temperature Solution Crystallization of Nanostructured Oxides and Thin Films. Chem. Eur. J. 2020, 26, 9157-9179. [CrossRef]

24. Xia, Y.; Yang, P.; Un, Y.S.; Wu, Y.; Mayers, B.; Gates, B.; Yin, Y.; Kim, F.; Yan, H. One-Dimensional Nanostructures: Synthesis, Characterization, and Applications. Adv. Mater. 2003, 15, 353-389. [CrossRef]

25. Jiang, W.; Ni, J.; Yu, K.; Zhu, Z. Hydrothermal synthesis and electrochemical characterization of $\mathrm{VO}_{2}$ (B) with controlled crystal structures. Appl. Surf. Sci. 2011, 257, 3253-3258. [CrossRef]

26. Yang, Z.; Ko, C.; Ramanathan, S. Oxide Electronics Utilizing Ultrafast Metal-Insulator Transitions. Annu. Rev. Mater. Res. 2011, 41, 337-367. [CrossRef]

27. Popuri, S.R.; Miclau, M.; Artemenko, A.; Labrugere, C.; Villesuzanne, A.; Pollet, M. Rapid hydrothermal synthesis of $\mathrm{VO}_{2}(\mathrm{~B})$ and its conversion to thermochromic $\mathrm{VO}_{2}$ (M1). Inorg. Chem. 2013, 52, 4780-4785. [CrossRef]

28. Guan, S.; Rougier, A.; Viraphong, O.; Denux, D.; Penin, N.; Gaudon, M. Two-Step Synthesis of $\mathrm{VO}_{2}(\mathrm{M})$ with Tuned Crystallinity. Inorg. Chem. 2018, 57, 8857-8865. [CrossRef] [PubMed]

29. Qazilbash, M.M.; Brehm, M.; Chae, B.; Ho, P.; Andreev, G.; Kim, B.; Yun, S.; Balatsky, A.; Maple, M.; Keilmann, F.; et al. Mott transition in $\mathrm{VO}_{2}$ revealed by infrared spectroscopy and nano-imaging. Science 2007, 318, 1750-1753. [CrossRef] [PubMed]

30. Valmalette, J.-C.; Gavarri, J.-R. High efficiency thermochromic $\mathrm{VO}_{2}(\mathrm{R})$ resulting from the irreversible transformation of $\mathrm{VO}_{2}(\mathrm{~B})$. Mater. Sci. Eng. B 1998, 54, 168-173. [CrossRef]

31. Zhu, J.; Zhou, Y.; Wang, B.; Zheng, J.; Ji, S.; Yao, H.; Luo, H.; Jin, P. Vanadium Dioxide Nanoparticle-based Thermochromic Smart Coating: High Luminous Transmittance, Excellent Solar Regulation Efficiency, and Near Room Temperature Phase Transition. ACS Appl. Mater. Interfaces 2015, 7, 27796-27803. [CrossRef]

32. Qu, Z.; Yao, L.; Li, J.; He, J.; Mi, J.; Ma, S.; Tang, S.; Feng, L. Bifunctional Template-Induced $\mathrm{VO}_{2} @ \mathrm{SiO}_{2} \mathrm{Dual}_{-\mathrm{Shelled} \mathrm{Hollow}}$ Nanosphere-Based Coatings for Smart Windows. ACS Appl. Mater. Interfaces 2019, 11, 15960-15968. [CrossRef] [PubMed] 